\title{
Attenuation of Negative Impacts by Micro Algae and Enriched Artemia Salina on Penaeus Monodon and Litopenaeus Vannamei Larval Culture
}

\author{
Karthik $\mathbf{R}^{1 *}$, Ramalingam $\mathrm{K}^{1}$, Yuvaraj $\mathrm{D}^{2}$, Vanitha $\mathrm{MC}^{1}$ and Muthezhilan $\mathbf{R}^{1}$
}

${ }^{1}$ Department of Marine Biotechnology and Centre for Marine Bioprospecting, AMET University (Declared as deemed to be University U/S 3 of UGC Act 1956), Kanathur, Chennai-603112, Tamil Nadu, India

${ }^{2}$ Department of Biotechnology, Vel Tech High Tech Engineering College, Avadi, Chennai-600 062, Tamil Nadu, India

\begin{abstract}
Providing a specific pathogen free (SPF) shrimps to the farmers is a big challenge that must be addressed to meet the demand. In general, microalgae are utilized in aquaculture as a live feed for the shrimps. However their importance in the attenuation of negative impacts of pathogenic microbial load, eutrophication and promotion of shrimps growth has to be delineated by experimental investigations to justify the above specific pathogen free shrimps. The present study was carried out to investigate the feeding of five different microalgae and algae enriched Artemia salina. Nauplii on digestive enzyme activity, growth, survival rate, microbial load on Penaeus monodon and Litopenaeus vannamei from Zoea to post larvae (20 stages) and other water quality. Microalgae such as Isochrysis galbana, Cheatoceros calcitrans, Tetraselmis sp, Chlorella sp and Nannochloropsis sp were obtained from AMET Microbial Culture Collection Centre, Department of Marine Biotechnology, AMET University. Penaeus monodon and Litopenaeus vannamei at PL 20 stage showed maximum protease and amylase (digestive enzyme) activity, maximum length and survival rate when fed with Artemia salina Nauplii enriched with $C$. calcitrans followed by Chlorella sp. On studying the water quality parameters such as, $\mathrm{pH}$, temperature, salinity, dissolved oxygen and ammonia it was found better in tank II where the shrimps were fed with Artemia salina enriched with $C$. calcitrans. Regarding the vibrio load at different stages of $P$. monodon and $L$. vannamei larvae and cultured water it was comparatively lower in tank II where the shrimps were fed with Cheatoceros calcitrans and enriched Artemia salina than other groups.
\end{abstract}

Keywords: Shrimp seeds; Micro algae; Artemia salina; Digestive enzyme; Water quality

\section{Introduction}

Shrimp farming is one of the most important aquaculture practices worldwide especially in Asia due to their high economic value. It is estimated that approximately more than 5 million metric tons of shrimp are annually produced but the current global demand for both the wild and farmed shrimps is approximately more than 6.5 million metric tons per annum [1]. Artificial culture of shrimps in grow out ponds has been intensified to keep shrimp production on par to the demand. As a sequel semi intensive and extensive methods of culture brought various ecological, economical and social issues [2]. In general, during the shrimp growth after metamorphosis it is considerably affected by the gradual change from planktonic to benthic existence coinciding with changes in the alimentation. During early post larval development, high mortality was noticed due to the changes in the gut associated digestive enzyme production levels $[3,4]$. The first feeding during the growth of any cultivable organism is the most 'critical phase' of their life cycle for their survival. Hence developing a new technology and new live feed may offer great hope for the future with a promise for blue revolution in the century to match the green revolution. Protein is the major component in the natural food of penaeids shrimps. Thus, feeding the penaids with protein rich live diets such as, phytoplankton such as microalgae $(2-20 \mu \mathrm{m})$ and zooplankton such as rotifers $(50-$ $200 \mu \mathrm{m})$ and brine shrimp, Artemia salina $(200-300 \mu \mathrm{m})$ can increase the gut associated digestive enzymes [5].

Micro algae and Artemia salina like zooplankton help to stabilize and improve the water quality improve the oxygen production, promote $\mathrm{pH}$ stabilization (the action of some excreted biochemical compounds along with the induction of behavioral processes like initial prey catching) and regulate disease causing bacterial population and above all the probiotics and stimulate immunity in the host animal [6]. The microalgae most frequently used in aquaculture include Chlorella, Tetraselmis, Isochrysis, Pavlova, Phaeodactylum, Chaetoceros, Nannochloropsis, Skeletonema and Thalassiosira [7]. Moreover, Artemia salina are biologically uncontaminated readily available and acceptable larval feed and established as a standard live feed for over $85 \%$ of marine species. The present study was aimed to examine the digestive enzymes (amylase and protease) activity, survival rate (\%), average growth $(\mathrm{mm})$, water quality parameters and bacterial (Vibrio) load in Penaeus monodon and Litopenaeus vannamei shrimp culture from zoea to postlarvae 20 stages by feeding with five different microalgae such as, Isochrysis galbana, Cheatoceros calcitrans, Tetraselmis sp, Chlorella sp and Nannochloropsis sp and algae enriched Artemia salina nauplii.

\section{Materials and Methods}

\section{Microalgae}

The five different microalgae such as Isochrysis galbana, Cheatoceros calcitrans, Tetraselmis sp, Chlorella $\mathrm{sp}$ and Nannochloropsis $\mathrm{sp}$ were obtained from AMET Microbial Culture Collection Centre, Department of Marine Biotechnology, AMET Unidversity.

*Corresponding author: Karthik R, Department of Marine Biotechnology and Centre for Marine Bioprospecting, AMET University (Declared as deemed to be University U/S 3 of UGC Act 1956), Kanathur, Chennai-603112, Tamil Nadu, India, Tel: 9710039843; E-mail: karthik1990vlr@gmail.com

Received June 10, 2015; Accepted June 20, 2015; Published June 22, 2015

Citation: Karthik R, Ramalingam K, Yuvaraj D, Vanitha MC, Muthezhilan R (2015) Attenuation of Negative Impacts by Micro Algae and Enriched Artemia Salina on Penaeus Monodon and Litopenaeus Vannamei Larval Culture. J Aquac Res Development 6: 365. doi:10.4172/2155-9546.1000365

Copyright: $\odot 2015$ Karthik R, et al. This is an open-access article distributed under the terms of the Creative Commons Attribution License, which permits unrestricted use, distribution, and reproduction in any medium, provided the original author and source are credited. 
Citation: Karthik R, Ramalingam K, Yuvaraj D, Vanitha MC, Muthezhilan R (2015) Attenuation of Negative Impacts by Micro Algae and Enriched Artemia Salina on Penaeus Monodon and Litopenaeus Vannamei Larval Culture. J Aquac Res Development 6: 365. doi:10.4172/21559546.1000365

Page 2 of 6

\section{Experimental animal}

The shrimp (nauplii $24 \mathrm{~h}$ ) of Penaeus monodon and Litopenaeus vannamei were obtained from a commercial shrimp hatchery located in Marakanam, Kanchipuram District, Tamil Nadu, India. They were kept in seawater with aeration for a period of $6 \mathrm{~h}$ in order to avoid any stress to the animals and then used for the experiments.

\section{Experimental design}

The experiments were conducted at the Department of Marine Biotechnology, AMET University, Chennai. A total of twelve $100 \mathrm{~L}$ glass tanks (Six tanks for Penaeus monodon and another six tanks for Litopenaeus vannamei) were added with $70 \mathrm{~L}$ of filtered seawater at $32 \%$ salinity and kept at ambient temperature $\left(28 \pm 1^{\circ} \mathrm{C}\right)$ and aerated continuously. The seeds were transferred in the tank with a stocking density of 75 nauplii per litre.

\section{Feeding schedule from zoea to post larvae}

The Zoea of Penaeus monodon and Litopenaeus vannamei kept in the experimental tanks were fed with five different microalgae such as Isochrysis galbana, Cheatoceros calcitrans, Tetraselmis sp, Chlorella sp and Nannochloropsis sp. On $1^{\text {st }}$ day of the Zoea (Z) of I-III stages were fed thrice with $30 \times 10^{4} \mathrm{cells} / \mathrm{ml}$ of algal cells. On the 2 nd day of the Mysis (M) (I-III/Postlarve 1) of Penaeus monodon and Litopenaeus vannamei were fed thrice with $40 \times 10^{4}$ cells $/ \mathrm{ml}$ of algal cells (Tables 1 and 2). From 3rd day up to 20th day they were fed thrice with $3-8 \mathrm{No} / \mathrm{ml}$ of Artemia salina nauplii enriched with different microalgae. The $24 \mathrm{~h}$ old Artemia salina nauplii enriched with Isochrysis galbana, Cheatoceros calcitrans, Tetraselmis sp, Chlorella sp and Nannochloropsis $\mathrm{sp}$ at 20, $30,40,50$ and $60 \times 10^{4}$ cells $/ \mathrm{ml}$ at $16 \mathrm{~h}$ and $9 \mathrm{~h}$ respectively for a period of $24 \mathrm{~h}$ as fed to Penaeus monodon and Litopenaeus vannamei. Filtered seawater was exchanged daily and the debris settled at the bottom was siphoned out without disturbing the animals. This experiment was conducted for a period of 20 days (PL20). At the end of the experiments the animals from all the experimental tanks were randomly selected and the survival rate and the average length were recorded.

\section{Digestive enzyme activities of shrimps fed with different mi- croalgae}

The shrimps were collected on 1st day (Zoea III stages) after naupliiar stage, $2^{\text {nd }}$ day (Mysis III), $5^{\text {th }}$ day (PL5), 10th day (PL10), $15^{\text {th }}$ day (PL15) and $20^{\text {th }}$ day (PL20) from all the experimental tanks and they are subjected for different enzyme analysis.

\section{Microbiological analysis}

Water samples were taken from the Penaeus monodon and Litopenaeus vannamei larval rearing tanks (all the experimental tanks)

\begin{tabular}{|c|c|c|c|c|c|}
\hline \multirow{2}{*}{$\begin{array}{c}\text { Water quality } \\
\text { parameters }\end{array}$} & \multicolumn{5}{|c|}{ Penaeus monodon } \\
\cline { 2 - 6 } Salinity (ppt) & $30 \pm 0.78$ & $30 \pm 0.13$ & $30 \pm 0.22$ & $30 \pm 0.81$ & $30 \pm 0.23$ \\
\hline pH & $8.0 \pm 0.17$ & $8.1 \pm 0.12$ & $8.1 \pm 0.12$ & $8.1 \pm 0.17$ & $8.1 \pm 0.15$ \\
\hline $\begin{array}{c}\text { Water } \\
\text { Temperature } \\
\left.\text { ( }{ }^{\circ} \mathbf{C}\right)\end{array}$ & $31 \pm 0.5$ & $31 \pm 0.5$ & $31 \pm 0.5$ & $31 \pm 0.5$ & $31 \pm 0.5$ \\
\hline $\begin{array}{c}\text { Dissolved } \\
\text { Oxygen(ml / } \\
\text { litre) }\end{array}$ & $5.58 \pm 0.12$ & $6.19 \pm 0.10$ & $5.73 \pm 0.19$ & $6.10 \pm 0.17$ & $5.70 \pm 0.32$ \\
\hline $\begin{array}{c}\text { Ammonia } \\
\text { (mg/litre) }\end{array}$ & $0.16 \pm 0.19$ & $0.14 \pm 0.11$ & $0.17 \pm 0.18$ & $0.15 \pm 0.13$ & $0.17 \pm 0.11$ \\
\hline
\end{tabular}

Table 1: Water quality parameters of both control and experimental larval rearing tanks of $P$. monodon.

\begin{tabular}{|c|c|c|c|c|c|}
\hline \multirow{2}{*}{$\begin{array}{c}\text { Water quality } \\
\text { parameters }\end{array}$} & \multicolumn{5}{|c|}{ Litopenaeus vannamei } \\
\cline { 2 - 6 } & Tank 1 & Tank 2 & Tank 3 & Tank 4 & Tank 5 \\
\hline Salinity (ppt) & $30 \pm 0.32$ & $30 \pm 0.43$ & $30 \pm 0.51$ & $30 \pm 0.19$ & $30 \pm 0.37$ \\
\hline pH & $8.0 \pm 0.11$ & $8.1 \pm 0.14$ & $8.1 \pm 0.02$ & $8.1 \pm 0.11$ & $8.1 \pm 0.03$ \\
\hline $\begin{array}{c}\text { Water } \\
\text { Temperature } \\
\text { (') } \mathbf{C})\end{array}$ & $31 \pm 0.5$ & $31 \pm 0.5$ & $31 \pm 0.5$ & $31 \pm 0.5$ & $31 \pm 0.5$ \\
\hline $\begin{array}{c}\text { Dissolved } \\
\text { Oxygen } \\
\text { (ml / litre) }\end{array}$ & $5.22 \pm 0.13$ & $6.10 \pm 0.10$ & $5.22 \pm 0.22$ & $6.08 \pm 0.18$ & $5.38 \pm 0.35$ \\
\hline $\begin{array}{c}\text { Ammonia } \\
\text { (mg/litre) }\end{array}$ & $0.17 \pm 0.19$ & $0.14 \pm 0.34$ & $0.16 \pm 0.32$ & $0.16 \pm 0.44$ & $0.17 \pm 0.23$ \\
\hline
\end{tabular}

Table 2: Water quality parameters of both control and experimental larval rearing tanks of $L$. vannamei.

during various larval stages of shrimps (i.e. nauplii, zoea, mysis and post larvae) and the Vibrio sp load was enumerated by growth on TCBS agar.

\section{Results and Discussion}

In general, traditional and non-scientific shrimp farms depend upon the shrimp seeds caught from the wild or those entered with the tides for stocking. Such seeds collected naturally from tides may have fortuitous infection with microbes and bound to affect shrimp culture. There is a demand for healthy and quality seeds throughout the year. Thus the successful shrimp culture is dependent upon stocking disease free, healthy seeds in the hatcheries [8]. The applications of microalgae for aquaculture are associated with nutrition and other biological activities [9]. The study of digestive enzymes constitutes a denominator role to consider the nutritional requirements of specific stages of development in shrimp. In the present study, the Zoea to Postlarvae 20 of Penaeus monodon and Litopenaeus vannamei were fed with five different microalgae such as, Isochrysis galbana, Cheatoceros calcitrans, Tetraselmis sp, Chlorella sp and Nannochloropsis sp and algae enriched Artemia salina. The protease activity at all the different stages of $P$. monodon and L. vannamei, the animals fed with Cheatoceros calcitrans and enriched Artemia salina exhibited a maximum protease activity of $(P$. monodon $17.02 \pm 0.01 \mathrm{U} / \mathrm{ml}$ and L. vannamei $16.55 \pm 0.08 \mathrm{U} /$ $\mathrm{ml})$ at $\mathrm{pH} 8$ and a minimum total activity of ( $P$. monodon $16.19 \pm$ $0.01 \mathrm{U} / \mathrm{ml}$ and $L$. vannamei $16.13 \pm 0.13 \mathrm{U} / \mathrm{ml}$ ) at $\mathrm{pH} 6$ followed by animals fed with Chlorella sp and enriched Artemia salina respectively. A decrease of protease activity was found from PL6 to PL20 stages of animals fed with other microalgae in all the groups. Same results were obtained when the animals fed with Artemia salina enriched with five different microalgae (Tables 3-7). Madhumathi and Rengasamy [3,4] also observed similar results, while studying the ontogenetic changes in the digestive enzyme of Penaeus monodon at Z3 to PL20 stages, when fed with $C$. calcitrans and other four different microalgae and enriched Artemia salina.

Regarding, the amylase activity all the different stages of $P$. monodon and Litopenaeus vannamei at different time intervals the Artemia nauplii fed with Cheatoceros calcitrans and enriched exhibited a maximum protease total activity at 15 minutes time interval $(P$. monodon $1.10 \pm 0.04 \mathrm{U} / \mathrm{ml}$ and $L$. vannamei $1.02 \pm 0.15 \mathrm{U} / \mathrm{ml})$ and it slightly decreased from 30 and 45 minutes (Tables 8-12). However, there was a gradual increase in the enzyme activity up to PL5, and then it decreased in PL10. Again it increased during the stages of PL15, the enzyme activity decreased during the stages of PL20.

Understanding the connection between the water quality and aquatic productivity is absolutely essential for optimum growth and production. The quality of water during the culture period will go down 
Citation: Karthik R, Ramalingam K, Yuvaraj D, Vanitha MC, Muthezhilan R (2015) Attenuation of Negative Impacts by Micro Algae and Enriched Artemia Salina on Penaeus Monodon and Litopenaeus Vannamei Larval Culture. J Aquac Res Development 6: 365. doi:10.4172/21559546.1000365

Page 3 of 6

\begin{tabular}{|c|c|c|c|c|}
\hline \multirow{2}{*}{ Algal Source } & \multicolumn{2}{|c|}{ Penaeus monodon } & \multicolumn{2}{c|}{ Litopenaeus vannamei } \\
\cline { 2 - 5 } & \multicolumn{2}{|c|}{ Total activity $\mathbf{( U / m l )}$} & \multicolumn{2}{c|}{ Total activity (U/ml) } \\
\cline { 2 - 5 } & $\mathbf{p H ~ 6}$ & $\mathbf{p H ~ 8}$ & $\mathbf{p H} \mathbf{6}$ & $\mathbf{p H ~ 8}$ \\
\hline Isochrysis sp & $15.10 \pm 0.2$ & $15.44 \pm 0.12$ & $15.17 \pm 0.09$ & $15.02 \pm 0.21$ \\
\hline Cheatoceros sp & $16.19 \pm 0.01$ & $17.02 \pm 0.31$ & $16.13 \pm 0.13$ & $16.55 \pm 0.08$ \\
\hline Tetraselmis sp & $15.02 \pm 0.4$ & $15.44 \pm 0.17$ & $15.17 \pm 0.18$ & $15.43 \pm 0.11$ \\
\hline Chlorella sp & $15.17 \pm 0.2$ & $15.55 \pm 0.07$ & $16.01 \pm 0.09$ & $16.35 \pm 0.09$ \\
\hline Nannochloropsis sp & $13.10 \pm 0.1$ & $13.44 \pm 0.22$ & $14.07 \pm 0.06$ & $14.61 \pm 0.03$ \\
\hline
\end{tabular}

Table 3: Protease activity of Z3-M3 stages of Penaeus monodon and Litopenaeus vannamei.

\begin{tabular}{|c|c|c|c|c|}
\hline \multirow{2}{*}{ Algal Source } & \multicolumn{2}{|c|}{ Penaeus monodon } & \multicolumn{2}{c|}{ Litopenaeus vannamei } \\
\cline { 2 - 5 } & \multicolumn{2}{|c|}{ Total activity (U/ml) } & \multicolumn{2}{c|}{ Total activity (U/ml) } \\
\cline { 2 - 5 } & $\mathbf{p H ~ 6}$ & $\mathbf{p H ~ 8}$ & $\mathbf{p H ~ 6}$ & $\mathbf{p H ~ 8}$ \\
\hline Isochrysis sp & $0.42 \pm 0.04$ & $20.09 \pm 0.3$ & $0.35 \pm 0.20$ & $18.11 \pm 0.13$ \\
\hline Cheatoceros sp & $0.49 \pm 0.03$ & $20.55 \pm 0.21$ & $0.44 \pm 0.11$ & $20.60 \pm 0.11$ \\
\hline Tetraselmis sp & $0.08 \pm 0.12$ & $19.48 \pm 0.18$ & $0.11 \pm 0.16$ & $19.12 \pm 0.21$ \\
\hline Chlorella sp & $0.47 \pm 0.19$ & $20.44 \pm 0.12$ & $0.40 \pm 0.14$ & $19.55 \pm 0.19$ \\
\hline Nannochloropsis sp & $0.44 \pm 0.08$ & $20.22 \pm 0.11$ & $0.38 \pm 0.12$ & $19.46 \pm 0.07$ \\
\hline
\end{tabular}

Table 4: Protease activity of PL 1-PL5 stages of Penaeus monodon and Litopenaeus vannamei.

\begin{tabular}{|c|c|c|c|c|}
\hline \multirow{2}{*}{ Algal Source } & \multicolumn{2}{|c|}{ Penaeus monodon } & \multicolumn{2}{c|}{ Litopenaeus vannamei } \\
\cline { 2 - 5 } & \multicolumn{2}{|c|}{ Total activity (U/ml) } & \multicolumn{2}{c|}{ Total activity (U/ml) } \\
\cline { 2 - 5 } & $\mathbf{p H ~ 6}$ & $\mathbf{p H ~ 8}$ & $\mathbf{p H}$ 6 & $\mathbf{p H ~ 8}$ \\
\hline Isochrysis sp & $0.39 \pm 0.21$ & $18.19 \pm 0.09$ & $0.28 \pm 0.13$ & $17.00 \pm 0.15$ \\
\hline Cheatoceros sp & $0.45 \pm 0.18$ & $19.42 \pm 0.13$ & $0.40 \pm 0.22$ & $20.32 \pm 0.19$ \\
\hline Tetraselmis sp & $0.15 \pm 0.13$ & $19.00 \pm 0.18$ & $0.17 \pm 0.18$ & $18.12 \pm 0.18$ \\
\hline Chlorella sp & $0.40 \pm 0.03$ & $19.20 \pm 0.09$ & $0.36 \pm 0.15$ & $19.30 \pm 0.16$ \\
\hline Nannochloropsis sp & $0.38 \pm 0.09$ & $18.20 \pm 0.06$ & $0.34 \pm 0.19$ & $17.22 \pm 0.12$ \\
\hline
\end{tabular}

Table 5: Protease activity of PL 6-PL10 stages of Penaeus monodon and Litopenaeus vannamei.

mainly due to the accumulation of organic wastes produced by the animals and unutilized feed. Thus, in this study, during the entire culture period some important water quality parameters such as, salinity, $\mathrm{pH}$, temperature, dissolved oxygen, and ammonia were monitored. Salinity is the most important factor influencing many functional responses of the organisms as metabolism, growth, migration, osmotic behavior, reproduction etc. The marine organisms maintain their internal salt concentration (salt concentration of blood and body fluids) by osmoregulation. In shrimp hatchery the recommended salinity range

\begin{tabular}{|c|c|c|c|c|}
\hline \multirow{2}{*}{ Algal Source } & \multicolumn{2}{|c|}{ Penaeus monodon } & \multicolumn{2}{c|}{ Litopenaeus vannamei } \\
\cline { 2 - 5 } & \multicolumn{2}{|c|}{ Total activity (U/ml) } & \multicolumn{2}{c|}{ Total activity (U/ml) } \\
\cline { 2 - 5 } & $\mathbf{p H ~ 6}$ & $\mathbf{p H ~ 8}$ & $\mathbf{p H ~ 6}$ & $\mathbf{p H ~ 8}$ \\
\hline Isochrysis sp & $0.11 \pm 0.12$ & $0.42 \pm 0.16$ & $0.09 \pm 0.08$ & $0.44 \pm 0.09$ \\
\hline Cheatoceros sp & $0.48 \pm 0.18$ & $1.12 \pm 0.11$ & $0.38 \pm 0.17$ & $1.14 \pm 0.16$ \\
\hline Tetraselmis sp & $0.20 \pm 0.19$ & $0.55 \pm 0.18$ & $0.17 \pm 0.14$ & $0.51 \pm 0.12$ \\
\hline Chlorella sp & $0.44 \pm 0.14$ & $0.65 \pm 0.13$ & $0.31 \pm 0.11$ & $0.59 \pm 0.09$ \\
\hline Nannochloropsis sp & $0.32 \pm 0.11$ & $0.44 \pm 0.18$ & $0.28 \pm 0.08$ & $0.41 \pm 0.07$ \\
\hline
\end{tabular}

Table 6: Protease activity of PL 11-PL15 stages of Penaeus monodon and Litopenaeus vannamei.

\begin{tabular}{|c|c|c|c|c|}
\hline \multirow{2}{*}{ Algal Source } & \multicolumn{2}{|c|}{ Penaeus monodon } & \multicolumn{2}{c|}{ Litopenaeus vannamei } \\
\cline { 2 - 5 } & \multicolumn{2}{|c|}{ Total activity (U/ml) } & \multicolumn{2}{c|}{ Total activity (U/ml) } \\
\cline { 2 - 5 } & $\mathbf{p H ~ 6}$ & $\mathbf{p H ~ 8}$ & $\mathbf{p H ~ 6}$ & $\mathbf{p H ~ 8}$ \\
\hline Isochrysis sp & $0.42 \pm 0.17$ & $0.20 \pm 0.13$ & $0.33 \pm 0.05$ & $0.18 \pm 0.19$ \\
\hline Cheatoceros sp & $0.55 \pm 0.11$ & $0.78 \pm 0.15$ & $0.42 \pm 0.13$ & $0.62 \pm 0.12$ \\
\hline Tetraselmis sp & $0.11 \pm 0.13$ & $0.56 \pm 0.12$ & $0.10 \pm 0.21$ & $0.32 \pm 0.14$ \\
\hline Chlorella sp & $0.45 \pm 0.14$ & $0.58 \pm 0.17$ & $0.36 \pm 0.19$ & $0.40 \pm 0.08$ \\
\hline Nannochloropsis sp & $0.33 \pm 0.18$ & $0.41 \pm 0.19$ & $0.30 \pm 0.09$ & $0.37 \pm 0.11$ \\
\hline
\end{tabular}

Table 7: Protease activity of PL 16-PL20 stages of Penaeus monodon and Litopenaeus vannamei.

is $28-35$ ppt [10]. In the present study the salinity was maintained at $30 \mathrm{ppt}$ in all the experimental tanks. Similarly Krishnaprakash [11] also maintained the salinity for the larval rearing of $P$. monodon at $31 \mathrm{ppt}$. During the culture period the $\mathrm{pH}$ was found to be 8.1 to 8.2 in the entire experimental tanks and the temperature was found to be in the range of $31 \pm 1.1^{\circ} \mathrm{C}$ in both the $P$. monodon and $L$. vannamei reared experimental tanks. Similarly Kannupandi et al. [10] also reported that the required range of $\mathrm{pH}$ for shrimp larval culture is 8.2-8.5.

Dissolved oxygen (DO) in the larvae/adult animals rearing water is an important factor for the respiration of aquatic organisms and also to maintain favorable chemical and hygienic environment of the water body. Moreover, it also controls many oxidation reactions and maintains aerobic conditions in water. Because, when oxygen level is very low and anaerobic conditions exist, nitrate is reduced into ammonia, which will be toxic to the larvae or adult in the culture water and it also increases the $\mathrm{pH}$. Furthermore, low-level of oxygen tension hampers metabolic performances in shrimp larvae and it will reduce the growth and finally cause huge mortality [12]. So, in this study the oxygen level in the culture medium was maintained in the desired

\begin{tabular}{|c|c|c|c|c|c|c|}
\hline \multirow{3}{*}{ Algal Source } & \multicolumn{3}{|c|}{ Penaeus monodon } & \multicolumn{3}{|c|}{ Litopenaeus vannamei } \\
\hline & \multicolumn{3}{|c|}{ Total activity $(\mathrm{U} / \mathrm{ml})$ at different time intervals (min) } & \multicolumn{3}{|c|}{ Total activity $(\mathrm{U} / \mathrm{ml})$ at different time intervals $(\mathrm{min})$} \\
\hline & 15 (min) & 30 (min) & 45 (min) & 15 (min) & 30 (min) & 45 (min) \\
\hline Isochrysis sp & $0.36 \pm 0.02$ & $0.32 \pm 0.11$ & $0.29 \pm 0.3$ & $0.34 \pm 0.18$ & $0.31 \pm 0.06$ & $0.28 \pm 0.12$ \\
\hline Cheatoceros sp & $1.10 \pm 0.04$ & $0.92 \pm 0.09$ & $0.80 \pm 0.07$ & $1.02 \pm 0.15$ & $0.78 \pm 0.08$ & $0.68 \pm 0.11$ \\
\hline Tetraselmis sp & $0.66 \pm 0.04$ & $0.58 \pm 0.12$ & $0.55 \pm 0.16$ & $0.64 \pm 0.09$ & $0.61 \pm 0.12$ & $0.56 \pm 0.18$ \\
\hline Chlorella sp & $0.78 \pm 0.01$ & $0.69 \pm 0.07$ & $0.66 \pm 0.09$ & $0.76 \pm 0.08$ & $0.71 \pm 0.09$ & $0.65 \pm 0.14$ \\
\hline Nannochloropsis sp & $0.38 \pm 0.06$ & $0.35 \pm 0.02$ & $0.31 \pm 0.03$ & $0.36 \pm 0.02$ & $0.30 \pm 0.11$ & $0.27 \pm 0.19$ \\
\hline
\end{tabular}

Table 8: Amylase activity of Z3-M3 stages of Penaeus monodon and Litopenaeus vannamei.

\begin{tabular}{|c|c|c|c|c|c|c|}
\hline \multirow{3}{*}{ Algal Source } & \multicolumn{3}{|c|}{ Penaeus monodon } & \multicolumn{3}{|c|}{ Litopenaeus vannamei } \\
\hline & \multicolumn{3}{|c|}{ Total activity $(\mathrm{U} / \mathrm{ml})$ at different time intervals $(\mathrm{min})$} & \multicolumn{3}{|c|}{ Total activity (U/ml) at different time intervals (min) } \\
\hline & 15 (min) & 30 (min) & 45 (min) & 15 (min) & 30 (min) & $45(\min )$ \\
\hline Isochrysis sp & $0.55 \pm 0.12$ & $0.52 \pm 0.08$ & $0.58 \pm 0.11$ & $0.57 \pm 0.08$ & $0.48 \pm 0.02$ & $0.62 \pm 0.16$ \\
\hline Cheatoceros sp & $0.92 \pm 0.17$ & $0.88 \pm 0.12$ & $0.94 \pm 0.15$ & $0.91 \pm 0.12$ & $0.86 \pm 0.06$ & $0.93 \pm 0.11$ \\
\hline Tetraselmis sp & $0.47 \pm 0.15$ & $0.39 \pm 0.15$ & $0.49 \pm 0.18$ & $0.46 \pm 0.11$ & $0.38 \pm 0.11$ & $0.52 \pm 0.13$ \\
\hline Chlorella sp & $0.66 \pm 0.11$ & $0.59 \pm 0.19$ & $0.69 \pm 0.12$ & $0.68 \pm 0.13$ & $0.61 \pm 0.03$ & $0.72 \pm 0.08$ \\
\hline Nannochloropsis sp & $0.52 \pm 0.09$ & $0.47 \pm 0.18$ & $0.56 \pm 0.09$ & $0.51 \pm 0.18$ & $0.47 \pm 0.19$ & $0.53 \pm 0.19$ \\
\hline
\end{tabular}

Table 9: Amylase activity of PL 1-PL5 stages of Penaeus monodon and Litopenaeus vannamei. 
Citation: Karthik R, Ramalingam K, Yuvaraj D, Vanitha MC, Muthezhilan R (2015) Attenuation of Negative Impacts by Micro Algae and Enriched Artemia Salina on Penaeus Monodon and Litopenaeus Vannamei Larval Culture. J Aquac Res Development 6: 365. doi:10.4172/21559546.1000365

Page 4 of 6

\begin{tabular}{|c|c|c|c|c|c|c|}
\hline \multirow{3}{*}{ Algal Source } & \multicolumn{3}{|c|}{ Penaeus monodon } & \multicolumn{3}{|c|}{ Litopenaeus vannamei } \\
\hline & \multicolumn{3}{|c|}{ Total activity $(\mathrm{U} / \mathrm{ml})$ at different time intervals $(\mathrm{min})$} & \multicolumn{3}{|c|}{ Total activity $(\mathrm{U} / \mathrm{ml})$ at different time intervals $(\mathrm{min})$} \\
\hline & 15 (min) & 30 (min) & 45 (min) & 15 (min) & 30 (min) & 45 (min) \\
\hline Isochrysis sp & $0.66 \pm 0.02$ & $0.58 \pm 0.14$ & $0.55 \pm 0.07$ & $0.64 \pm 0.18$ & $0.61 \pm 0.5$ & $0.56 \pm 0.08$ \\
\hline Cheatoceros sp & $1.13 \pm 0.08$ & $0.98 \pm 0.11$ & $0.90 \pm 0.16$ & $1.11 \pm 0.09$ & $0.93 \pm 0.15$ & $0.88 \pm 0.12$ \\
\hline Tetraselmis sp & $0.38 \pm 0.12$ & $0.35 \pm 0.05$ & $0.31 \pm 0.02$ & $0.36 \pm 0.04$ & $0.30 \pm 0.07$ & $0.27 \pm 0.16$ \\
\hline Chlorella sp & $0.78 \pm 0.03$ & $0.69 \pm 0.15$ & $0.66 \pm 0.19$ & $0.76 \pm 0.12$ & $0.71 \pm 0.17$ & $0.65 \pm 0.17$ \\
\hline Nannochloropsis sp & $0.36 \pm 0.14$ & $0.32 \pm 0.13$ & $0.29 \pm 0.09$ & $0.34 \pm 0.13$ & $0.31 \pm 0.04$ & $0.28 \pm 0.07$ \\
\hline
\end{tabular}

Table 10: Amylase activity of PL 6-PL10 stages of Penaeus monodon and Litopenaeus vannamei.

\begin{tabular}{|c|c|c|c|c|c|c|}
\hline \multirow{3}{*}{ Algal Source } & \multicolumn{3}{|c|}{ Penaeus monodon } & \multicolumn{3}{|c|}{ Litopenaeus vannamei } \\
\hline & \multicolumn{3}{|c|}{ Total activity $(\mathrm{U} / \mathrm{ml})$ at different time intervals (min) } & \multicolumn{3}{|c|}{ Total activity $(\mathrm{U} / \mathrm{ml})$ at different time intervals (min) } \\
\hline & 15 (min) & 30 (min) & 45 (min) & 15 (min) & 30 (min) & 45 (min) \\
\hline Isochrysis sp & $0.56 \pm 0.09$ & $0.52 \pm 0.09$ & $0.48 \pm 0.7$ & $0.57 \pm 0.08$ & $0.52 \pm 0.10$ & $0.45 \pm 0.13$ \\
\hline Cheatoceros sp & $1.09 \pm 0.03$ & $1.15 \pm 0.10$ & $0.99 \pm 0.16$ & $1.12 \pm 0.12$ & $0.96 \pm 0.09$ & $0.96 \pm 0.18$ \\
\hline Tetraselmis sp & $0.66 \pm 0.12$ & $0.62 \pm 0.12$ & $0.58 \pm 0.18$ & $0.64 \pm 0.11$ & $0.62 \pm 0.18$ & $0.58 \pm 0.17$ \\
\hline Chlorella sp & $0.88 \pm 0.16$ & $0.76 \pm 0.13$ & $0.69 \pm 0.12$ & $0.85 \pm 0.19$ & $0.71 \pm 0.06$ & $0.62 \pm 0.04$ \\
\hline Nannochloropsis sp & $0.58 \pm 0.07$ & $0.55 \pm 0.05$ & $0.49 \pm 0.14$ & $0.51 \pm 0.05$ & $0.49 \pm 0.02$ & $0.40 \pm 0.08$ \\
\hline
\end{tabular}

Table 11: Amylase activity of PL 11-PL15 stages of Penaeus monodon and Litopenaeus vannamei.

\begin{tabular}{|c|c|c|c|c|c|c|}
\hline \multirow{3}{*}{ Algal Source } & \multicolumn{3}{|c|}{ Penaeus monodon } & \multicolumn{3}{|c|}{ Litopenaeus vannamei } \\
\hline & \multicolumn{3}{|c|}{ Total activity $(\mathrm{U} / \mathrm{ml})$ at different time intervals (min) } & \multicolumn{3}{|c|}{ Total activity $(\mathrm{U} / \mathrm{ml})$ at different time intervals (min) } \\
\hline & 15 (min) & 30 (min) & 45 (min) & 15 (min) & 30 (min) & 45 (min) \\
\hline Isochrysis sp & $0.66 \pm 0.19$ & $0.58 \pm 0.05$ & $0.55 \pm 0.07$ & $0.64 \pm 0.13$ & $0.61 \pm 0.10$ & $0.56 \pm 0.05$ \\
\hline Cheatoceros sp & $1.07 \pm 0.02$ & $1.18 \pm 0.11$ & $0.75 \pm 0.15$ & $1.02 \pm 0.18$ & $0.98 \pm 0.04$ & $0.72 \pm 0.19$ \\
\hline Tetraselmis sp & $0.58 \pm 0.14$ & $0.55 \pm 0.07$ & $0.49 \pm 0.12$ & $0.51 \pm 0.03$ & $0.49 \pm 0.16$ & $0.40 \pm 0.11$ \\
\hline Chlorella sp & $0.67 \pm 0.17$ & $0.59 \pm 0.02$ & $0.69 \pm 0.02$ & $0.68 \pm 0.07$ & $0.63 \pm 0.05$ & $0.65 \pm 0.14$ \\
\hline Nannochloropsis sp & $0.36 \pm 0.06$ & $0.32 \pm 0.06$ & $0.29 \pm 0.17$ & $0.34 \pm 0.08$ & $0.31 \pm 0.09$ & $0.28 \pm 0.06$ \\
\hline
\end{tabular}

Table 12: Amylase activity of PL 16-PL20 stages of Penaeus monodon and Litopenaeus vannamei.

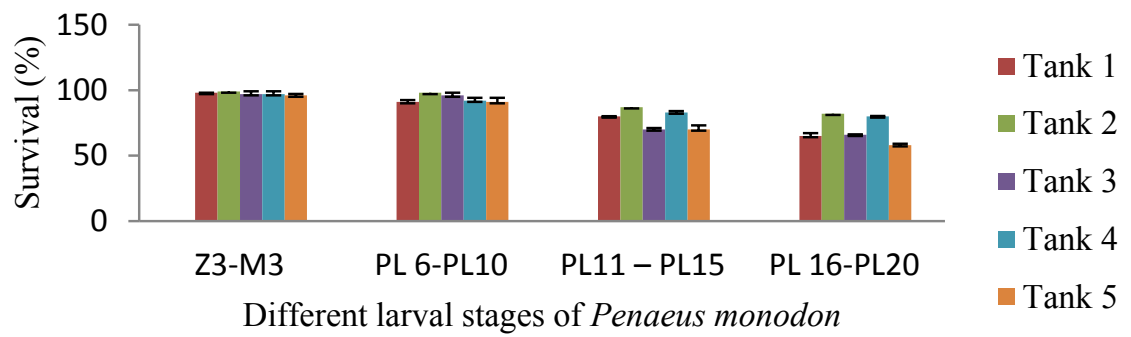

Figure 1: Survival rate of different larval stages of Penaeus monodon reared in both control and experimental tanks.

range by aeration continuously during the whole culture period. In $P$. monodon culture while checking the dissolved oxygen it was found to be higher in experimental tank $2(6.19 \pm 0.17 \mathrm{ml} /$ litre $)$ followed by tank $4(6.10 \pm 0.17 \mathrm{ml} /$ litre $)$. Moreover the ammonia was found to be low in experimental tank $2(0.14 \pm 0.11 \mathrm{mg} /$ litre $)$ followed by tank 4 $(0.15 \pm 0.13 \mathrm{ml} /$ litre). In $L$. vannamei culture whereas checking the dissolved oxygen it was found to be higher in experimental tank $2(6.10$ $\pm 0.10 \mathrm{ml} /$ litre $)$ followed by tank $4(6.08 \pm 0.18 \mathrm{ml} /$ litre $)$. Moreover the ammonia was found to be low in experimental tank $2(0.14 \pm 0.34 \mathrm{mg} /$ litre) followed by tank $4(0.16 \pm 0.44 \mathrm{ml} /$ litre $)$.

In the present study, whereas monitoring the survival rate of the nauplii of $P$. monodon and L. vannamei, it was found to be higher in all the experimental tanks (Figures 1 and 2). At the end of the culture period (PL20) the average length of all the post larvae was found to be maximum higher in the experimental tank 2 where the animals fed with Cheatoceros calcitrans and enriched Artemia salina (Figures 3 and 4). Madhumathi and Rengasamy [3,4] also observed the similar results, like high survival rate, length and weight of Zoea - PL I of P. monodon fed with C. calcitrans and PL I-PL20 stages fed with C. calcitrans enriched Artemia naupli diets. They also stated that, the Zoea to PLI of shrimps had high protein content of $51 \%$ followed by carbohydrate $6 \%$ and lipid 50\% when it was fed with C. calcitrans.

In normal, diseases in aquaculture practices are mostly caused by luminous bacteria Vibrio harveyi, and it has been referred to as the largest economic loss in the shrimp aquaculture due to mass mortalities. Furthermore, in general pathogenic microbes always remain in the water as opportunistic pathogens and they attack the larvae only when the larvae are weak due to environmental stress or nutritional deficiency [13]. During larval rearing stages different microbes may enter the hatchery system through the eggs and live feeds such as algae and Atremia sp. In the present study, while checking the vibrio load at different stages of $P$. monodon and L. vannamei larvae and cultured water it was found to be comparatively lower in tank 2 where the animals fed with Cheatoceros calcitrans and enriched Artemia salina than other groups (Figures 5-8). 
Citation: Karthik R, Ramalingam K, Yuvaraj D, Vanitha MC, Muthezhilan R (2015) Attenuation of Negative Impacts by Micro Algae and Enriched Artemia Salina on Penaeus Monodon and Litopenaeus Vannamei Larval Culture. J Aquac Res Development 6: 365. doi:10.4172/21559546.1000365

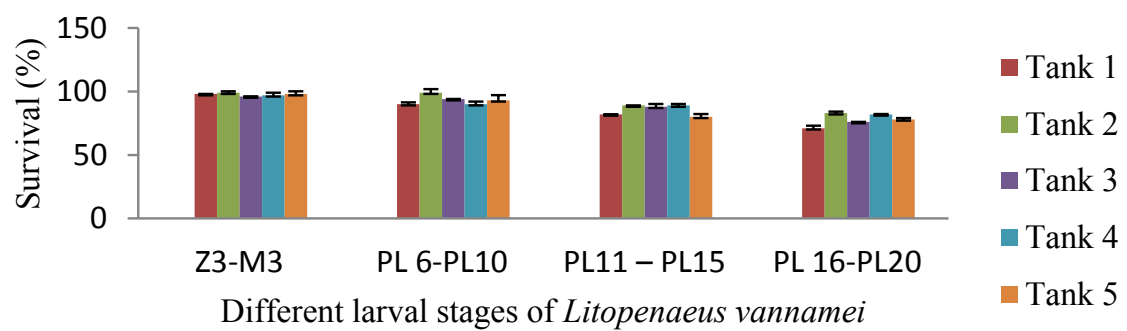

Figure 2: Survival rate of different larval stages of Litopenaeus vannamei reared in both control and experimental tanks.

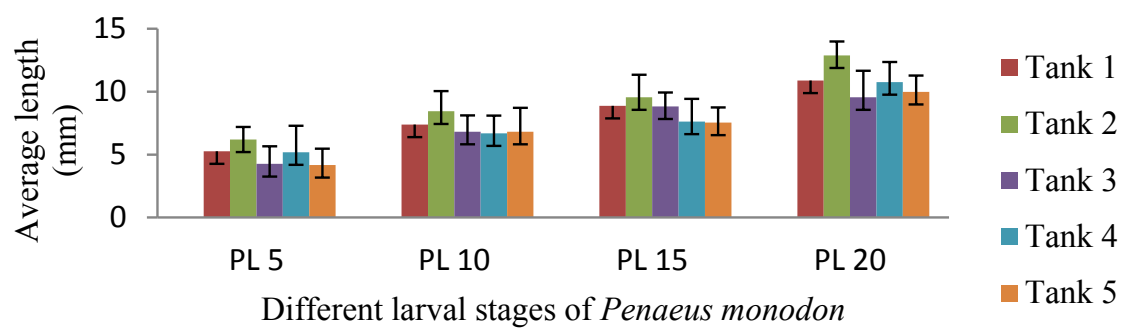

Figure 3: The average length $(\mathrm{mm})$ of $P$. monodon post larvae reared in both control and experimental tanks.

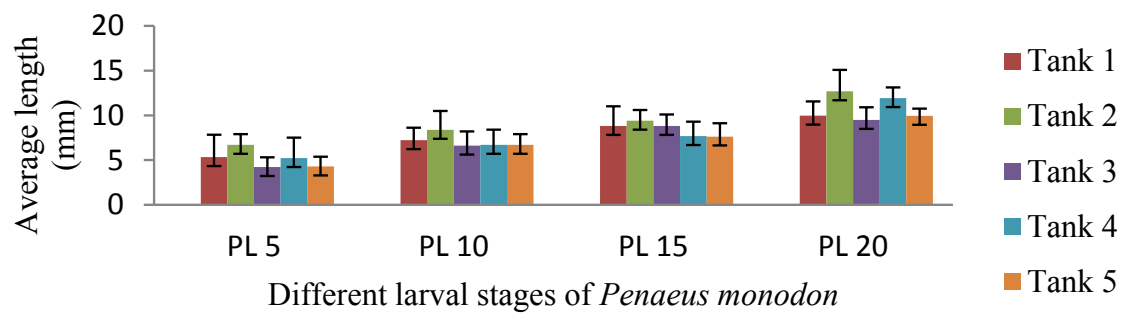

Figure 4: The average length $(\mathrm{mm})$ of L.vannamei post larvae reared in both control and experimental tanks.

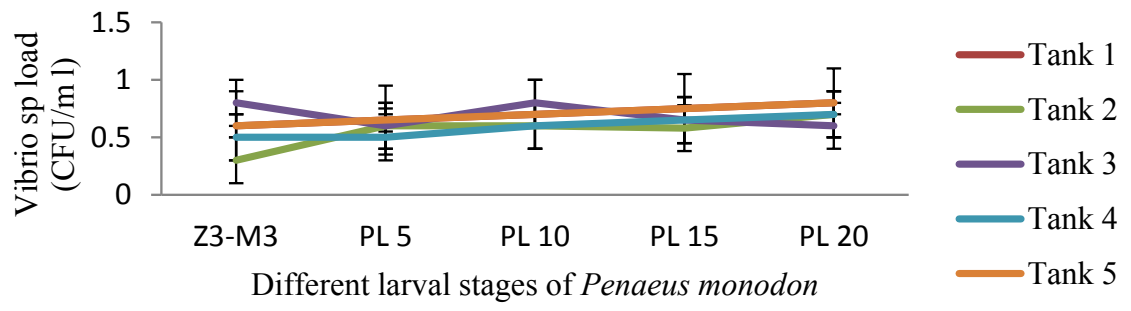

Figure 5: Bacterial loads (Vibriosis) in the rearing water of $P$. monodon (different stages) of both control and experimental tanks.

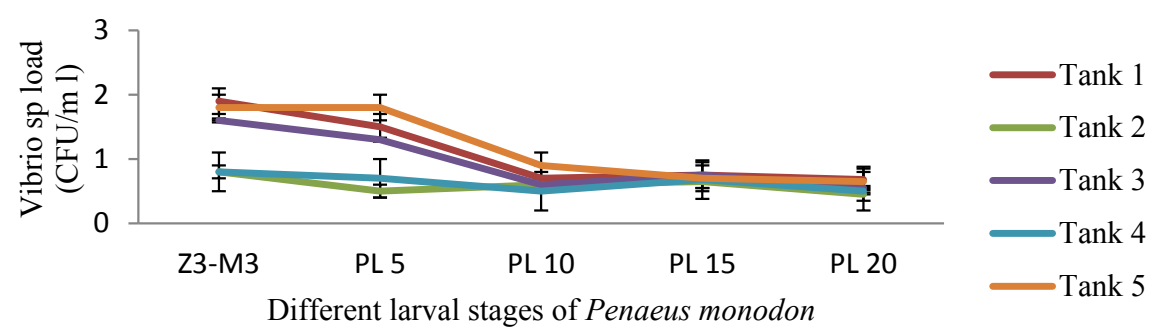

Figure 6: Bacterial loads (Vibriosis) in the larvae of $P$. monodon (different stages) of both control and experimental tanks. 
Citation: Karthik R, Ramalingam K, Yuvaraj D, Vanitha MC, Muthezhilan R (2015) Attenuation of Negative Impacts by Micro Algae and Enriched Artemia Salina on Penaeus Monodon and Litopenaeus Vannamei Larval Culture. J Aquac Res Development 6: 365. doi:10.4172/21559546.1000365

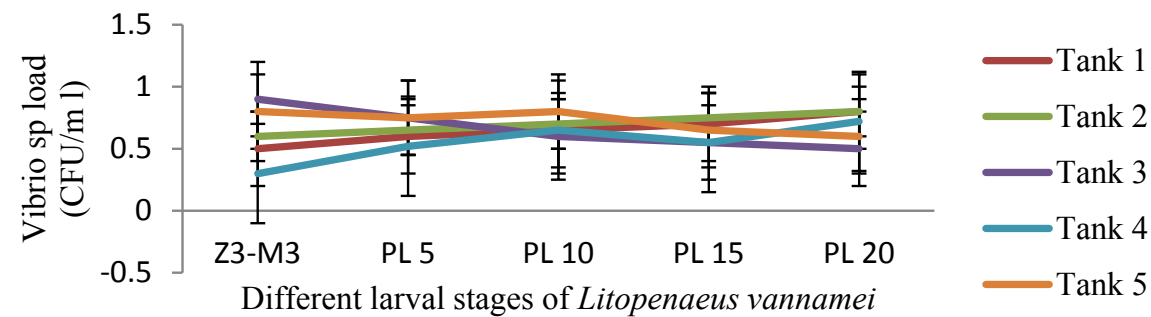

Figure 7: Bacterial loads (Vibriosis) in the rearing water of $L$. vannamei (different stages) of both control and experimental tanks

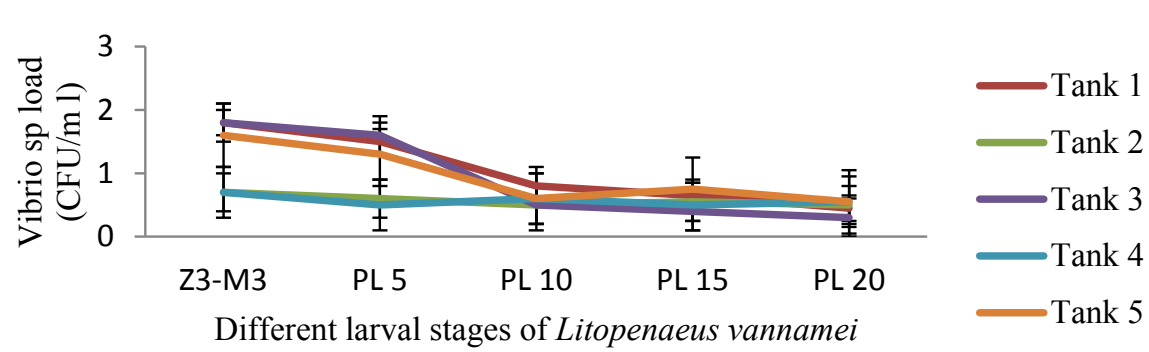

Figure 8: Bacterial loads (Vibriosis) in the larvae of L. vannamei (different stages) of both control and experimental tanks.

\section{Conclusion}

Since the demand for shrimp products in world markets continues to increase, the continuous supply of healthy, inexpensive and robust shrimp seed stocks to the farmers is important to maintain production of adult shrimps. Microalgae stay an important part of the aquaculture production chain particularly for hatchery shrimp feed, in spite of expensive culture installation and high production cost. From the results, it is concluded that, the use of Cheatoceros calcitrans and enriched Artemia salina will promote the successful production of shrimp larvae in hatcheries and reduce the potential negative impact of shrimp farming on the environment like, organic matter accumulation, ammonification, eutrophication and water toxicity and increase the productivity of the farms to the benefit of local economies.

\section{References}

1. Karthik R, Jaffar Hussain A, Muthezhilan R (2014) Effectiveness of Lactobacillus $\mathrm{sp}$ (AMET1506) as Probiotic against Vibriosis in Penaeus monodon and Litopenaeus vannamei Shrimp Aquaculture. Biosciences Biotechnology Research Asia 11: 297-305.

2. FAO (2012a) The State of World Fisheries and Aquaculture 2012. Food and Agricultural Organization of the United Nations.

3. Madhumathi M, Rengasamy R (2011a) Effect of Algal Enriched Artemia salina. On the Growth and Digestive Enzyme Activity of Penaeus monodon from Zoea to Postlarval 20. American-Eurasian J Agronomy 4: 28-33.

4. Madhumathi M, Rengasamy R (2011b) Evaluation of nutritional Parameters and carotenoid pigment from Penaeus monodon of Zoea - PL 20 stages fed with live algal diet and Artemia enriched algal diet. Recent Research in Science and Technology 3: 76-82.

5. Annon (2000) The state of world fisheries and aquaculture. Food and agriculture organisation of the United Nations, Rome, Italy.

6. Raja R, Hemaiswarya S, Rengasamy R (2007) Exploitation of Dunaliella for $\beta$-carotene production. Applied Microbiology and Biotechnology 74: 517-523.
7. Spolaore P, Joannis-Cassan C, Duran E, Isambert A (2006) Commercial application of microalgae. J Bioscience and Bioengineering 101: 87-96.

8. Soundarapandian P, Babu R (2010) Effect of Probiotics on the Hatchery Seed Production of Black Tiger Shrimp, Penaeus monodon (Fabricius). Int Anim Veterin Advan 2: 9-15

9. Hemaiswarya S, Raja R, Kumar RR, Ganesan V, Anbazhagan C (2011) Microalgae: a sustainable feed source for aquaculture. World J Microbiology and Biotechnology 27:1737-1746.

10. Kannupandi T, Soundarapandian P, Anantharaman P (2002) Hatchery operation manual for Penaeus monodon Fabricius.

11. Krishnaprakash R (2007) Studies on the production of high quality shrimp (Penaeus monodon Fabricius) seed in a commercial hatchery.

12. Gilles Le M (2001) Environmental factor affect immune response and resistance in crustaceans.

13. Sivakumar N, Sundararaman M, Selvakumar G, Varalakshmi P, Balasubramaniem (2014) Lactobacillus SP. a potent probiotic for disease free shrimp aquaculture. Int J Recent Scientific Research 5: 1031-1045. 